\title{
PENGGUNAAN SOFTWARE ENCORE DALAM MENULIS ARANSEMEN LAGU BAGI GURU SENI BUDAYA SMP DI KABUPATEN SERANG
}

\author{
FIRMAN SAPARDANI \\ SMPN 2 MANCAK \\ e-mail: sapardanifirman@gmail.com
}

\begin{abstract}
ABSTRAK
Salah satu kendala yang dihadapi oleh guru seni budaya yang bukan berlatarbelakang seni musik adalah dalam mengajarkan materi aransemen terutama dalam hal penulisan notasi balok, sekaligus dalam hal membunyikan hasil aransemennya. Tujuan dari penelitian ini adalah memperkenalkan keberadaan berbagai software musik yang diharapkan dapat membantu para guru seni budaya dalam menulis dan membaca notasi sekaligus dapat mendengarkan hasil aransemennya. Metode penelitian pada penelitian ini menggunakan Class Action Research atau penelitian tindakan kelas dengan pendekatan kualitatif, agar para guru memperoleh gambaran dalam menerapkan di kelas masing-masing secara tahap demi tahap. Pemanfaatan software Encore ini dapat memecahkan masalah yang dihadapi para guru seni budaya SMP khususnya di Kabupaten Serang dalam mengajar seni musik terutama dalam materi aransemen..
\end{abstract}

Kata Kunci: software encore, aransemen, guru seni budaya.

\section{ABSTRACT}

One of the obstacles faced by art and culture teachers who do not have a background in music art is in teaching arrangement material, especially in terms of writing block notation, as well as in sounding the results of the arrangement. The purpose of this study is to introduce the existence of various music software which is expected to help art and culture teachers in writing and reading notation as well as being able to listen to the results of their arrangements. The research method in this study uses Class Action Research or classroom action research with a qualitative approach, so that teachers get an overview of implementing it in their respective classes step by step. Utilization of this Encore software can solve the problems faced by middle school arts and culture teachers, especially in Serang Regency in teaching the art of music, especially in arrangement material.

Keywords: software encore, arrangement, art and culture teacher.

\section{PENDAHULUAN}

Mata pelajaran Seni Budaya memiliki sifat multilingual, multidimensional, dan multikultural. Multilingual bermakna pengembangan kemampuan mengekspresikan diri secara kreatif dengan berbagai cara dan media seperti bahasa rupa, bunyi, gerak, peran dan berbagai keterpaduannya. Multidimensional bermakna pengembangan beragam kompetensi meliputi konsep, apresiasi, dan kreasi dengan cara memadukan secara harmonis unsur estetika, logika, kinestetika, dan etika. Sifat multikultural mengandung makna pendidikan seni menumbuhkembangkan kesadaran dan kemampuan apresiasi terhadap beragam seni budaya. Hal ini merupakan wujud pembentukan sikap demokratis yang memungkinkan seseorang hidup secara beradab serta toleran dalam masyarakat dan budaya yang majemuk.

Guru sebagai pendidik profesional mempunyai tugas, fungsi, dan peran penting dalam mencerdaskan kehidupan bangsa, peran tersebut bisa diraih apabila guru mempunyai kapabilitas, kapasitas, dan kompetensi yang mumpuni. Guru yang profesional diharapkan mampu memberikan kontribusi pada pembangunan nasional yaitu dengan mempersiapkan peserta didik agar memiliki pengetahuan, keterampilan serta kompetensi sosial dan spiritual yang baik bagi siswanya.

Seiring dengan perkembangan zaman, tantangan guru-guru seni menjadi sangat "serius" dalam hal mempertahankan dan mengembangkan sekaligus mempelajari seni budaya untuk ditularkan kepada siswa-siswi kita sebagai generasi penerus yang harus memiliki cita, rasa, dan 
karsa bidang seni. Guru harus kreatif dalam mengembangkan keterampilannya, guru juga harus punya strategi dalam mengajarkan ilmu serta keterampilannya (Grimonia: 2014) dan dewasa ini dengan kemajuan teknologi khususnya dalam bidang penulisan notasi musik diharapkan membantu para guru seni budaya dalam memecahkan permasalahan yang selama ini menjadi kendala.

Guru-guru seni budaya SMP di Kabupaten Serang yang tergabung dalam MGMP Seni Budaya SMP banyak yang bukan berlatarbelakang seni atau bukan lulusan dari jurusan seni, hal ini menuntut guru-guru tersebut untuk terus berusaha meningkatkan kompetensi penguasaan materi yang diajarkannya baik seni rupa, musik, tari, dan seni teater baik secara teori ataupun secara praktek. Banyak guru yang merasa dirinya tidak punya rasa musikal padahal sebenarnya tetapi sebenarnya mereka kurang mendapat pengembangan dalam bidang musik (Banoe: 2013). Salahsatu kendala yang dirasakan oleh guru seni budaya yang mengajar seni musik adalah kemampuan dalam menulis motasi balok dan membuat aransemen musik serta medengarkan hasil aransemen itu sendiri.

Materi aransemen musik yang termasuk ke dalam materi kompetensi dasar yang harus diberikan kepada peserta didik menjadi materi yang sulit untuk diajarkan guru kepada peserta didiknya, hal ini disebabkan karena ada beberapa tahap atau ilmu yang harus dikuasai diantaranya adalah mengenal notasi lagu asli dan menuliskannya dengan benar, mengenal ilmu harmoni, dan bisa mendengarkan hasil aransemennya untuk menghindari kesalahan.

Kehadiran software musik diharapkan membantu dalam proses dan hasil belajar mengajar. Selain memotivasi guru untuk lebih banyak belajar, kehadiran encore ini juga diharapkan menjadi motivasi bagi peserta didik, karena bagi mereka penggunaan multimedia bisa mempermudah pemahaman materi yang diberikan (Putera \& Ishartiwi: 174).

Efektivitas dan kebermanfaatan teknologi aplikasi musik dalam hal ini encore yang ditampilkan berbentuk multimedia dalam meningkatkan pemahaman dalam hal materi pelajaran musik khususnya materi arransemen lagu sederhana dua suara. Selain kreatif penggunaan media pembelajaran berbasis teknologi juga menbant siswa belajar efektif (adrianus dkk:2009)

Aransemen sendiri merupakan cara yang digunakan agar guru dan siswa bisa lebih kreatif dalam mengolah ritme, melodi, harmoni, dinamika, timbre dan ekspresi (firmansyah:2016)

\section{METODE PENELITIAN}

Metode yang digunakan dalam penelitian ini adalah metode Class Action Research (CAR) menurut Danzen dan Lincoln (1994) pendekatan kualitatif memudahkan peneliti dalam menemukan pemecahan masalah dalam berbagai bidang disiplin ilmu. Maryaeni (2012) dalam hal ini peneliti mengobservasi langsung guru-guru yang sedang mengkuti kegiatan workshop seni musik di MGMP Seni Budaya Kabupaten Serang.

Dalam metoda tindakan kelas peneliti melakukan suatu tindakan yang diamati secara terus menerus, dilihat plus minusnya sampai pada upaya menentukan tindakan yang paling tepat (Arikunto 2013), lebih lanjut Metler (2011) mengatakan bahwa penelitian tindakan merupakan penelitian sistematis yang dilaksanakan oleh guru, penyelenggara pendidikan, guru konseling untuk mengumpulkan seputar cara kerja sekolah, cara guru mengajar dan cara siswa belajar. berikut:

Bila digambarkan, desain penelitian tindakan kelas yang dilakukan adalah sebagai 


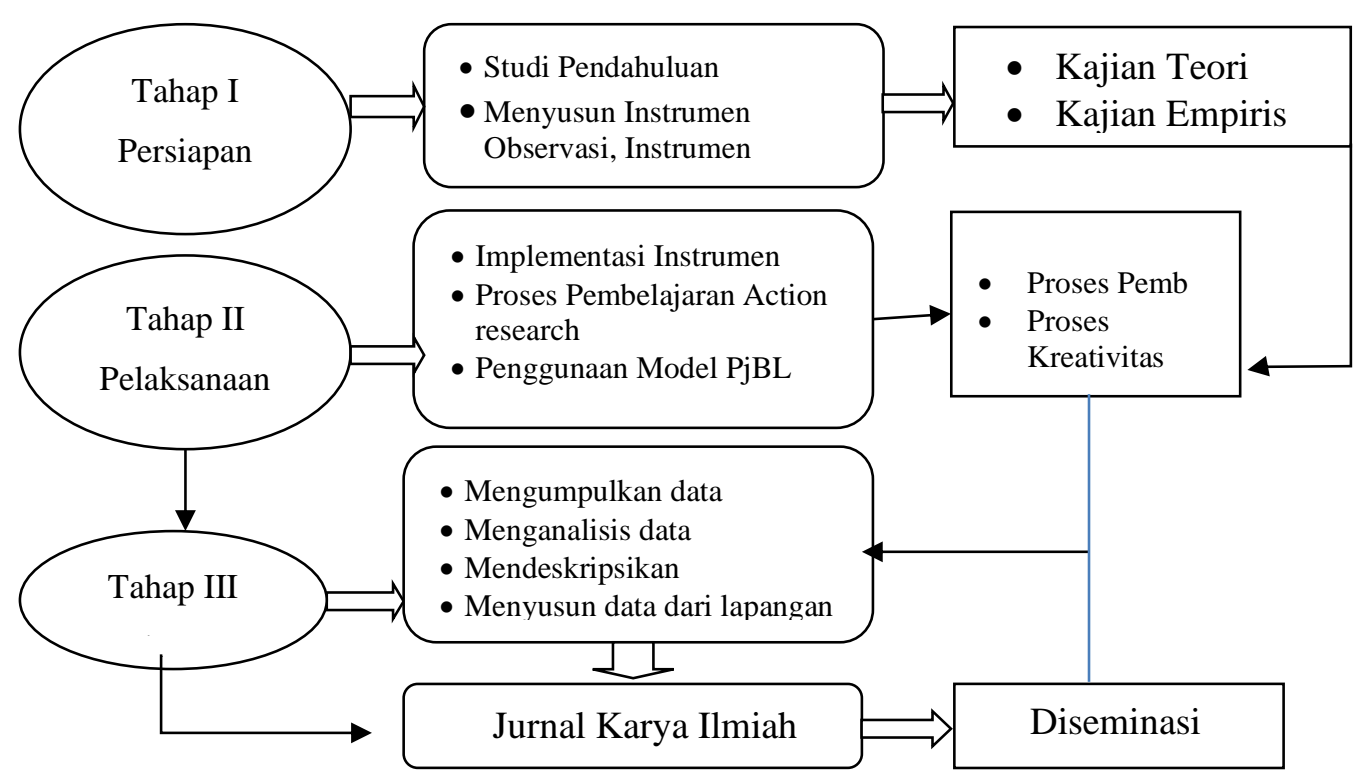

Diagram 1 Design Penelitian Pembelajaran

Pada tahap studi pendahuluan peneliti mengikuti kegiatan MGMP di Kabupaten Serang yang diikuti oleh guru-guru seni budaya SMP, dari hasil pengamatan diketahui bahwa kendala yang dihadapi oleh guru seni budaya ketika membahas tentang aransemen adalah kesulitan dalam menuliskan notasi balok dan menentukan suara 2(dua) serta mengetahui hasil aransemen yang telah dibuat sehingga peneliti memutuskan menggunakan aplikasi Encore untuk membantu para guru seni budaya tersebut, adapun siklus yang digunakan menggunakan konsep penelitian tindakan seperti yang dilakukan oleh Lewin (1990) yang didasarkan atas empat komponen pokok yaitu 1) Perencanaan (planning), 2) tindakan (acting), pengamatan (observing), dan 4) refleksi (reflecting).

\section{HASIL DAN PEMBAHASAN}

Guru seni budaya yang mengajarkan seni musik harus memiliki kompetensi dalam menulis dan membaca notasi balok karena hampir semua partitur baik vokal maupun instrumen alat musik ditulis dalam nota balk, sehingga kehadiran aplikasi Encore sangat membantu guru dalam menulis dan mebaca notasi. Pengamatan dan tindakan pada penelitian ini dilaksanakan selama 3 (tiga) kali pertemuan yaitu pada tanggal 5, 12, dan 19 Pebruari 2020 diikuti oleh 40 peserta yang dilaksanakan di sanggar MGMP Seni Budaya SMP Kabupaten Serang yaitu di SMPN 1 Kramatwatu.

\section{Hasil}

Dari hasil pengamatan peneliti yang dilakukan selama mengikuti workshop yang dilaksanakan di MGMP Seni Budaya Kabupaten Serang, penulis menemukan masalah yang dihadapi guru seni budaya yaitu kesulitan ketika menulis notasi balok, membaca dan mengaransemen sederhana pada materi ansambel.

Penulisan notasi balok harus menggunakan buku khusus yang sudah ada garis paranadanya, sehingga jika tidak ada buku paranada, guru harus membuat terlebih dahulu garis paranadanya dan pembuatan garis paranada tersebut menyita waktu yang sebenarnya bisa dmanfaatkan guru untuk hal lain. Kendala berikut nya adalah dalam menulis dan membunyikan not, hal ini dikarenakan tidak semua guru seni budaya mempunyai bayangan nada atau dapat menyanyikan nada dengan tepat. Dari berbagai kesulitan tersebut penulis mencoba memperkenalkan aplikasi komputer musik yang bisa menulis dan bisa juga dibunyikan, 
sehingga dapat digunakan dalam pembelajaran seni musik khususnya dalam materi aransemen sederhana.

Pembelajaran musik tidak bisa dilepaskan dengan penggunaan lambang nada atau notasi karena semua partitur baik vokal maupun instrumen pasti menggunakan partitur, partitur terdiri dari partitur notasi angka dan partitur notasi balok. Kelebihan notasi balok adalah secara visual progres naik dan turun nadanya bisa terlihat, sedangkan jika menggunakan notasi angka, hal ini tidak terlihat karena deretan angka-angkanya terlihat sejajar. Oleh karena itu penggunaan notasi balok membantu siswa untuk dapat membaca notnya. Proses selama workshop dan penelitian ini berlangsung dapat dijabarkan sebagai berikut:

\section{Siklus 1}

Pada siklus 1 ini peneliti mencoba memperkenalkan aplikasi encore kepada para guru, diawali dengan menginstal aplikasi ini ke laptop masing-masing. Setelah itu diperkenalkan cara mengoperasikan Encore dengan memperkenalkan fitur-fitur yang terdapat pada Encore yaitu:

\section{(B) Encore - [Untitled - 1]}

\begin{tabular}{|c|c|c|c|c|c|c|c|c|c|c|c|}
\hline ת File & Edit Notes & Mea: & ure & & ore & View & ows & Setı & Hels & & \\
\hline Voice - & $A \Leftrightarrow \mathbb{E}$ & e & 1 & 口 & (2) & Thru A1 & $Q$ & 1 & M1 & 15 & 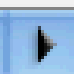 \\
\hline
\end{tabular}

1. Judul

Setelah di ketik judul lagu maka anti akan muncul pada tulisan "untitled"

2. File

File terdiri dari : New, New Default Score, Open, Close, Save, Save As, Export, Extrack Part, dan print.

3. Edit

Terdiri dari: cut, copy, paste dan undo

4. Note

Pada bagian ini terdiri dari not dan nilai not, tanda tempo, dinamik dan tanda tanda lainnya.

5. Measure

Measure terdiri dari: Measure, mengatur tempo, birama

6. Score

Score terdiri dari: Tambah halaman, tambah birama, membuat judul

7. View

View berguna untuk mengubah tampilan partitur

Dari keseluruhan anggota MGMP yang mengikuti workshop pada siklus 1 didapat data sebagai berikut:

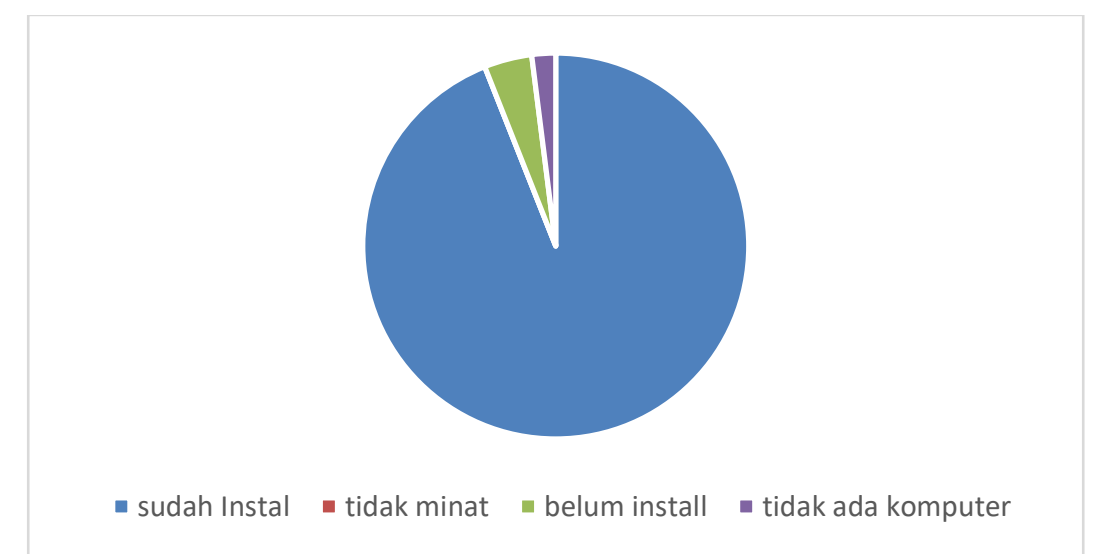

Gambar 2: peserta yang menginstal aplikasi encore 
Dari data di atas dapat disimpulkan bahwa dari 40 peserta yang mengikuti workshop: 37 orang sukses menginstal, 2 orang belum instal, 0 orang yang tidak berminat, dan 1 orang yang tidak membawa komputer. Setelah mengikuti proses penginstalan kemudian peserta diajarkan bagaimana membuka aplikasi, memahami penggunaan aplikasi dan mencoba membuat deret notasi menggunakan encore. Dimulai dengan membuat tangga nada $\mathrm{C}$ mayor, setelah berbagai diskusi dan percobaan akhirnya sebagian besar para peserta dapat mengerti penggunaan aplikasi ini.

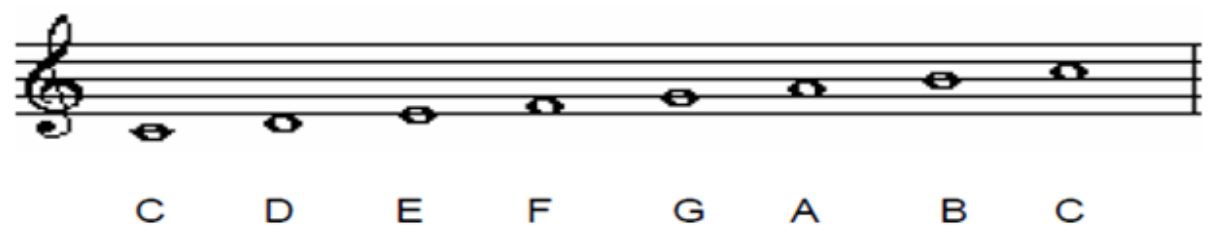

Gambar 3 : materi pada siklus 1 berikut:

Dari 40 peserta yang bisa membuat sampai tahap ini bisa digambarkan melalui

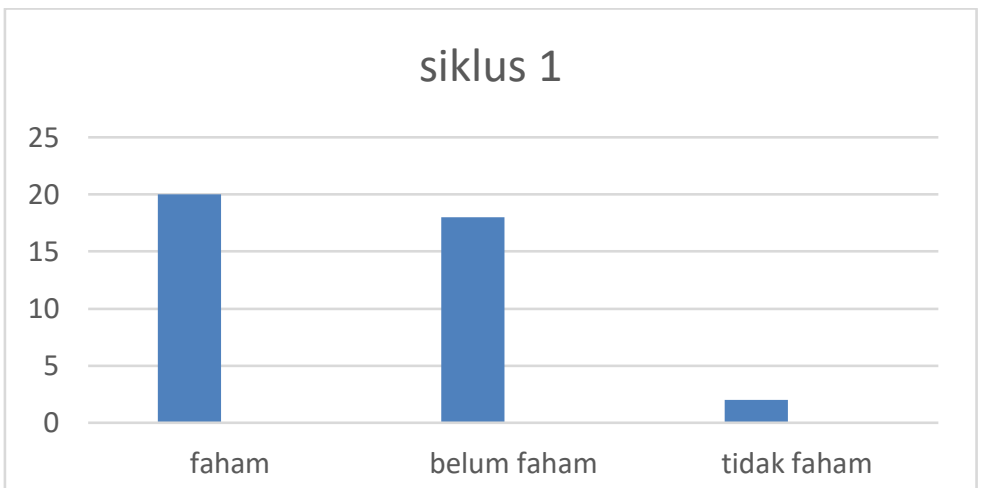

Gambar 4: pemahaman guru dalam menerapkan encore pada siklus 1

Dari tabel di atas dapat di simpulkan bahwa dari 40 peserta yang dapat mengunakan cara menggunakan encore baru 20 orang, sehingga perlu diskusi dan pembimbingan lagi agar pemahaman para guru bisa bertambah tindakan yang dilakukan adalah dengan merancang apa yang akan dilakukan pada siklus 2 yaitu memberikan contoh membuat notasi lagu sederhana yang berjudul Boneka Abdi.

\section{Siklus 2}

Setelah mengevaluasi kegiatan dari siklus 1, maka penulis memberikan tambahan materi untuk lebih menguasai encore dengan cara mencoba menyalin lagu Boneka abdi dai notasi angka menjadi notasi balok.

Adapun notasi angkanya adalah

\section{Boneka abdi}

$533 . \mid 422$. 32 | 1234 | 55 5.|

Abdi teh Ayena Gaduh hiji boneka

$533 .|422| 1355 \mid$.1 . . . |

Teu kinten saena sareng lucuna

$2222 \mid 234$. | 33333 3| 345 . |

Ku Abdi dierokan erokna sae pisan

$533 . \mid 422$.| $13355 \mid 1$. . . |

Cing mangga tingali boneka abdi 
Dari salinan notasi ini didapat hasil sebagai berikut:

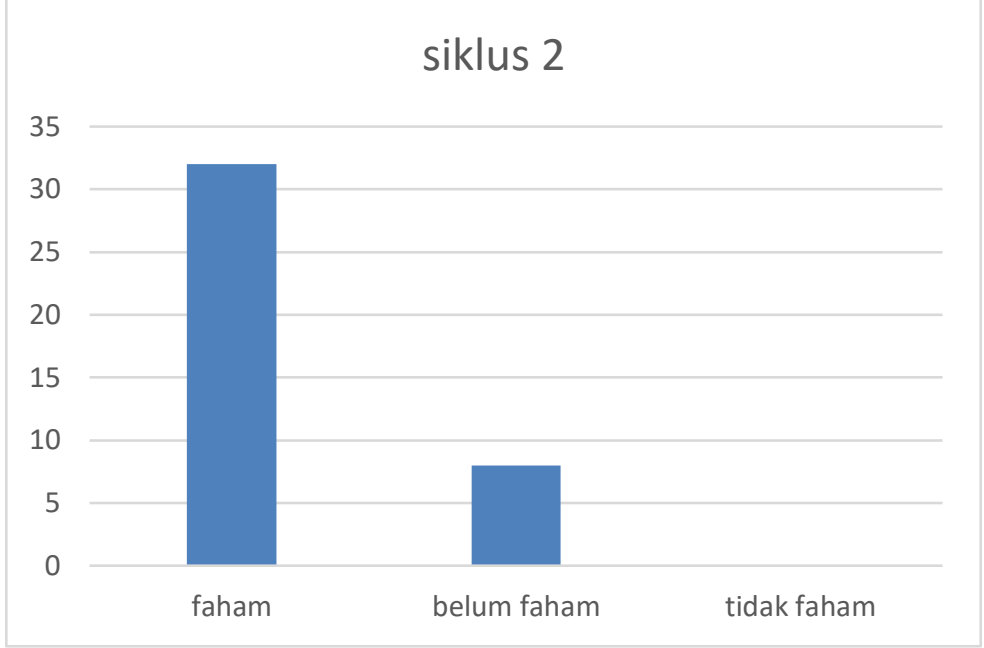

Gambar 6. Progres perkembangan siklus 2

Dari diagram pada siklus 2 dapat dideskripsikan bahwa seteah melalui tahapan latihan menulis notas angka menjadi notasi balok dengan menggunaan encore, para guru semakin terampil dan bisa membuat partitur lagu menggunakan notasi balok, sekaligus dapat mendengar hasil penulisannya. Sehingga jika ditemuka notasi yang salah maka para guru dapat mengubahnya secara langsung. Dari 40 peserta yang mengikuti workshop 32 orang sudah dapat menuliskannya dengan benar, sedangkan yang belum bisa dengan lancar masih ada 8 orang, sehingga untuk menambah pemahaman aplikasi ini penulis memberikan tugas mengaransemen lagu Boneka Abdi menjadi aransemen 2 suara.

\section{Siklus 3}

Pada tugas siklus 3 ini para peserta dibagi menjadi 4 kelompok, mereka mendiskusikan aransemen yang akan dibuat, melalui kegiatan diskusi inilah guru-guru yang belum faham betul terbantu untuk bertanya kepada guru-guru yang sudah faham. Sehingga permasalahan cara penggunaan encore guna membantu guru seni budaya dalam membuat partitur notasi balok dan aransemen dapat ditemukan solusinya.

Menurut Danny Ivanno(2013) dalam proses mengaransemen setiap kelompok menentukan terlebih dahulu langkah-langkah atau tahapan dalam mengaransemen, diantaranya:

1. Menentukan lagu yang akan diaransemen yaitu Boneka Abdi

2. Menentukan alur melodi suara 2

Alur melodi dibagi 3 bagian yaitu:

1) Melodi searah yaitu melodi yang selalu mengiuti melodi pertama dengan jarak ters

2) Melodi menyimpang yaitu melodi yang keluar dari struktur akor

3) Melodi berlawanan, melodi yang berlawanan dengan melodi utama

3. Menentukan nada dasar

4. Menentukan akor

5. Membuat suara 2

6. Mengevaluasi

\section{Pembahasan}

Dari hasil pengamatan proses penelitian yang dilakukan melalui siklus 1, siklus2, dan siklus 3 dapat disimpulkan bahwa penggunaan encore membantu para guru seni budaya untuk membuat notasi balok dengan lebih cepat pada pembelajaran ansambel dan pembuatan partitur lagu Ivanno(2013).

Pembelajaran musik yang dilakukan pada acara workshop di MGMP Seni Budaya Kabupaten Serang banyak memberikan manfaat dan kontribusi bagi orang yang mempelajarinya, kita bisa melihat kelas menjadi aktif dan kreatif. Keaktifan ini bisa dilihat dari 
aktifitas yang dilakukan oleh para guru, mereka begitu antusias dan konsentrasi ketika membuat notasi pada aplikasi encore kemudian mendengarkan nada nada yang dibuatnya, bahkan banyak yang kreatif dalam membuat nada-nada suara dua nya. Seperti yang diungkapkan oleh Halimah (2015) bahwa musik dapat memberikan suasana hangat, kenyamanan, dan motivasi sehingga pembelajaran akan berjalan lebih fokus.

Berdasarkan pengamatan yang dilakukan, penggunaan aplikasi encore ini selain membantu para guru juga membangkitkan motivasi dalam memberikan pengajaran seni budaya, karena selain waktu yang efisien juga hasil yang didapatkan lebih bagus dan lebih modern. Motivasi yang muncul dikarenakan para guru mendapatkan pengalaman yang baru dan menambah percaya diri untuk mengajarkan materi notasi dan aransemen yang selama ini dirasakan sebagai beban mengajar yang berat oleh guru terutama yang bukan berlatarbelakang seni musik. Hal ini sangat penting mengingat sosok guru di depan siswa diharapkan mampu membangkitkan rasa musikalitas anak yang belum terlihat, sehingga melalui pembelajaran musik encore ini bisa menumbuhkembangkan potensi siswa dalam belajar seni musik.

Tahapan membuat notasi balok lagu Boneka Abdi diawali dengan membuka aplikasi encore dengan memilih menu New, setelah itu memilih angka 1 staff stave per system, system per page 5, measure per system 4, birama 4/4, memilih Kunci C, kemudian pilih create, nanti akan tampil gambar seperti berikut ini:

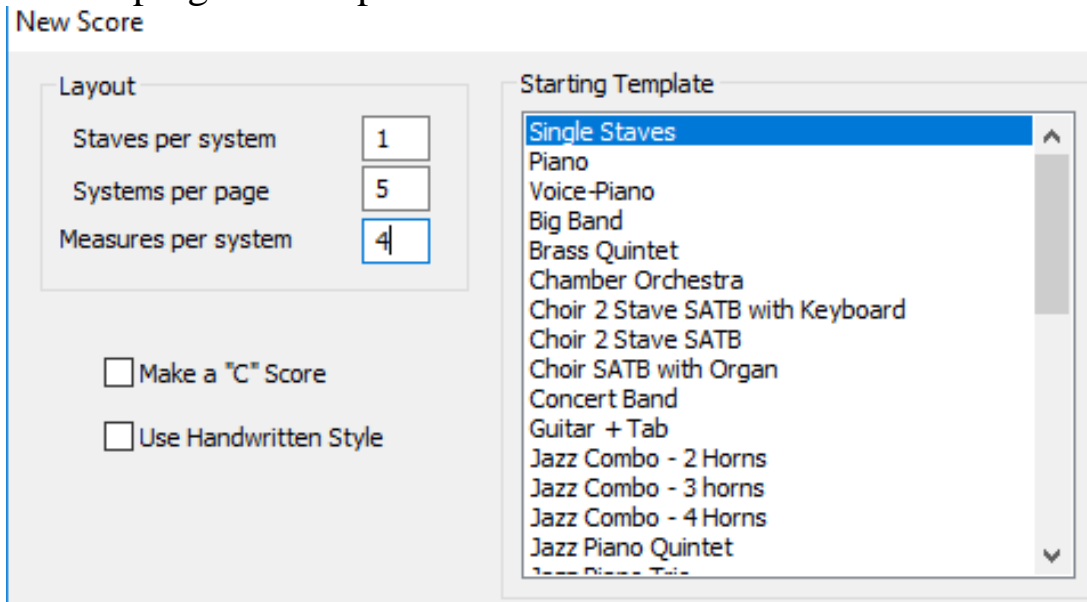

Create, then open Wizard Windows Create Cancel Help

Gambar. 7. Bagian awal membuka aplikasi

Setelah mengetik create akan muncul partitur kosong dan kita tinggal memilih not dan memyimpannnya sesuai lagu

(D) Encore - [Untitled - 2]

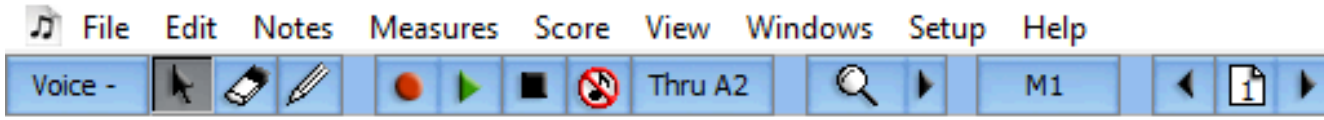

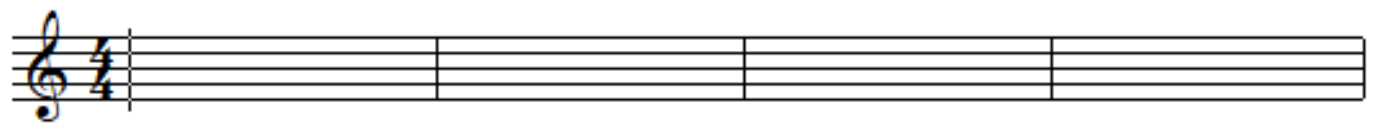

Gambar. 8 Partitur Kosong yang belum diberi notasi

Setelah muncul partitur kosong kita tinggal memasukan not sesuai lagunya, kemudian kita bisa melengkapi partitur dengan memasukan judul, pencipta, tempo, nada dasar atau memasukan nama yang mengaransir lagu tersebut. Tetapi sebelumnya diperkenalkan terlebih dahulu tentang teori dasar tentang notasi balok yaitu: 
EDUTECH : Jurnal Inovasi Pendidikan Berbantuan Teknologi

Vol. 1 No. 3 November 2021, e-ISSN : 2797-0140 | p-ISSN : 2797-0590

Tabel 1.Nama dan Nilai Not

\begin{tabular}{|c|c|c|c|}
\hline $\begin{array}{l}\text { BENTUK } \\
\text { NADA }\end{array}$ & NAMA NADA & NILAI NADA & $\begin{array}{c}\text { TANDA } \\
\text { ISTIRAHAT }\end{array}$ \\
\hline $\mathbf{0}$ & Not Penuh & 4 ketukan & $=$ \\
\hline$\delta$ & Not Setengah (1/2) & 2 ketukan & \\
\hline & Not Seperempat ( $1 / 4)$ & 1 ketukan & \\
\hline & Not Seperdelapan ( 1/8 ) & $1 / 2$ ketukan & \\
\hline & Not Seperenambelas ( $1 / 16)$ & $1 / 4$ ketukan & $y$ \\
\hline
\end{tabular}

Untuk memberikan judul dan kelengkapan nama pencipta serta tanda lain tinggal klik tanda score kemudian pilih text element disana akan tertera kolom kolom yang harus diisi.

Hasil dari siklus ke 2 dari workshop encore ini, alhamdulillah para peserta dapat menyalin lagu Boneka Abdi dari notasi angka menjadi notasi balok seperti pada gambar berikut ini:

\section{BONEKA ABDI}
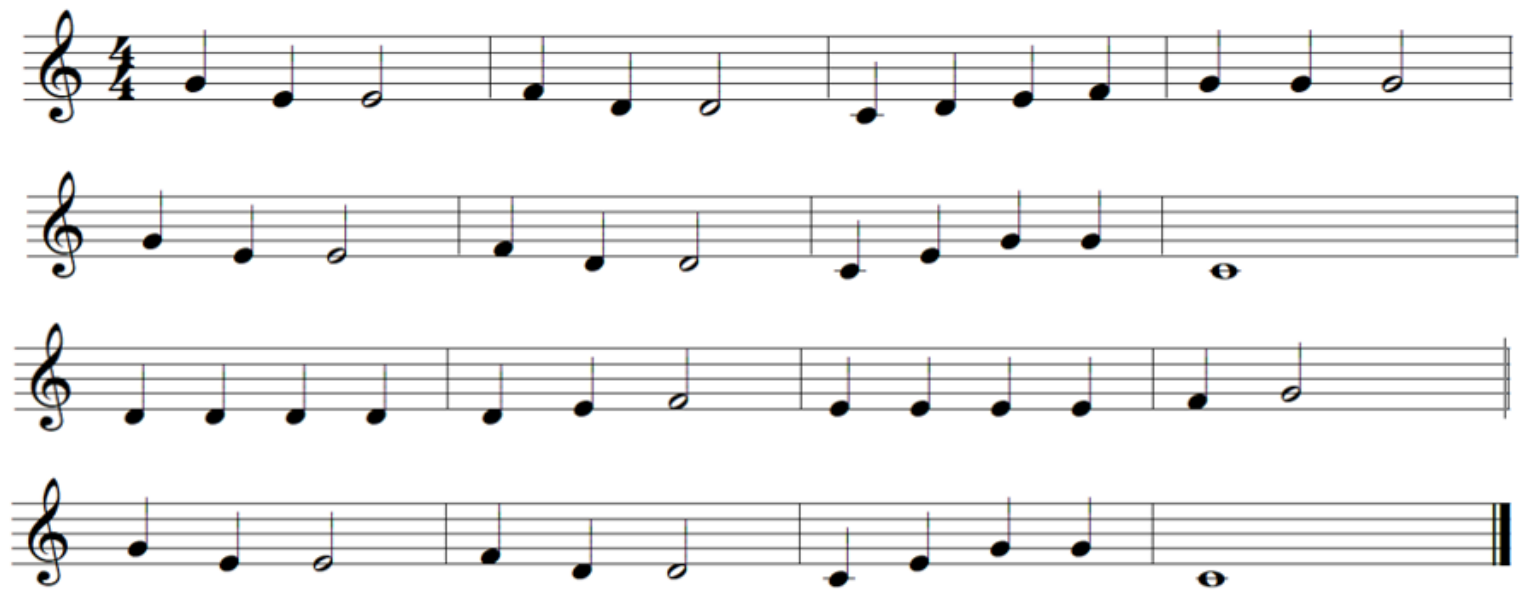

Gambar. 10 Notasi Balok “ Boneka Abdi"

Setelah selesai membuat notasi balok lagu Boneka Abdi, di siklus ketiga para peserta dibagi menjadi beberapa kelompok untuk mencoba berdiskusi membuat aransemen lagu tersebut.

hasil dari diskusi dari kegiatan tersebut, terciptalah sebuah aransemen lagu Boneka Abdi sebagai berikut: 

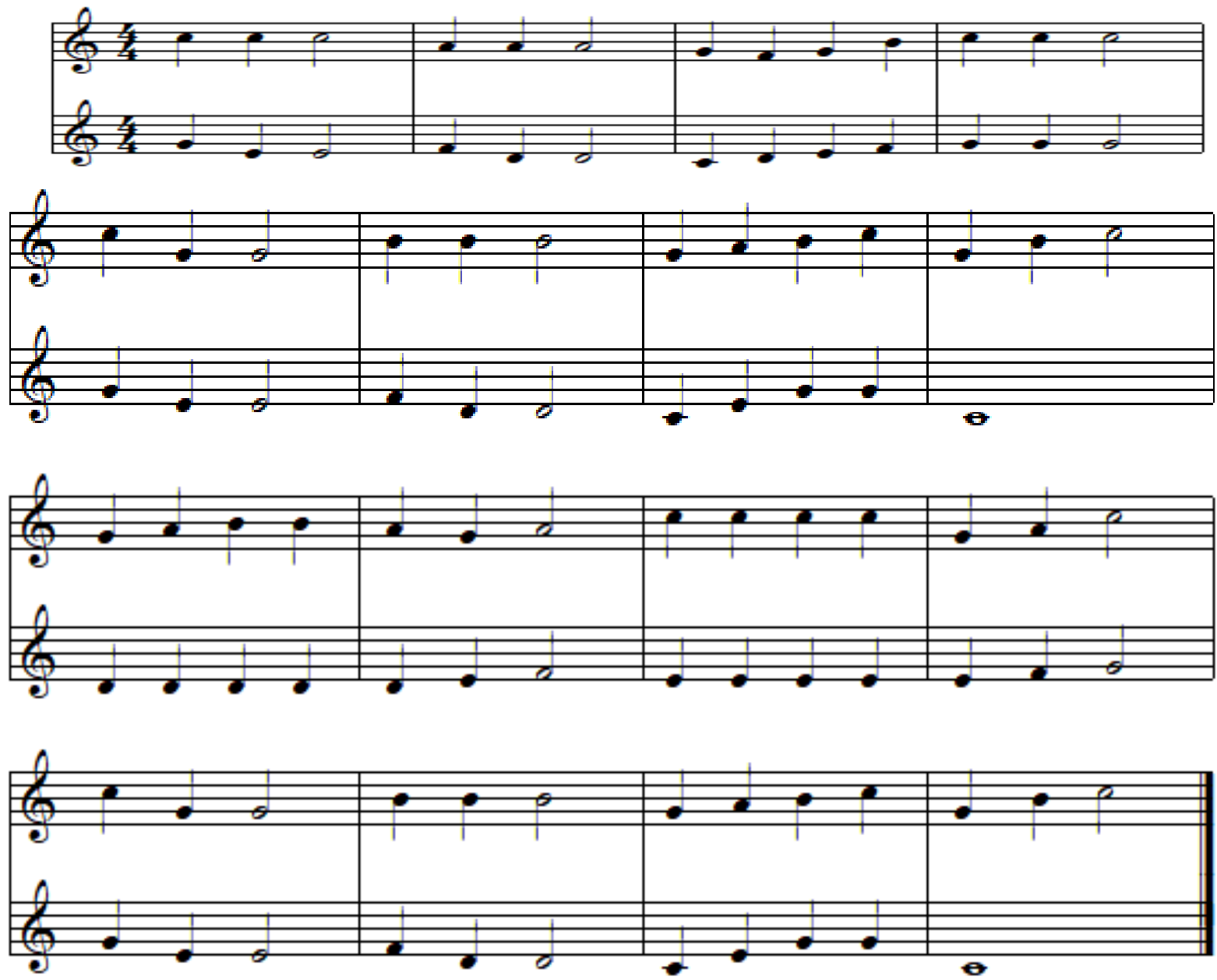

Gambar. 11 Aransemen 2 suara lagu Boneka Abdi

Menurut Widodo (dalam Kaestri 2021) mengemukakan bahwa ketika seseorang membuat aransemen musik, akan memunculkan ide-ide kreatif berdasarkan ekspresi pembuatnya. Lebih lanjut Artanto (2016) mengungkapkan bahwa Mengaransemen ini pula merupakan proses kreatif dalam bermusik, sehingga mengaransemen sederhana bagi guru seni budaya merupakan hal yang tepat dipelajari guru, selain menjadi motivasi, mengenal penggunaan teknologi komputer musik, juga menumbuhkembangkan kreativitas baik bagi guru maupun bagi siswanya.

Sebagian besar Ilmu dasar teori musik dan mengaransemen para guru sudah memahaminya seperti nama dan nilai not, menentukan akor, mencari Tonika, Ters, Kwart, Kwint, Oktaf, serta teori mengaransemen yang lainnya, tetapi belum mahir dalam mempraktekannya, sehingga melalui pembelajaran ini semua permasalahan tentang teori dasar musik dan aransemen dapat dibahas dan para guru mendapatkan pencerahan yang maksimal.

Bagi guru yang berhasil memahami cara penggunaan Encore ini dan mempraktekan aransemen, mereka melanjutkan dengan mengaransemen lagu lain, bahkan tertarik untuk mempelajari aplikasi musik yang lain. 


\section{KESIMPULAN}

Kesimpulan yang bisa kita ambil dari kegiatan penelitian ini adalah:

1. Perlu adanya kegiatan yang lebih variatif dan menarik pada kegiatan yang diadakan oleh MGMP Seni Budaya Kabupaten Serang sebagai motivasi bagi guru seni budaya untuk terus belajar.

Kegiatan yang dilakukan dengan menggali sumber sumber materi dan pemanfaatan teknologi menjadi suatu kebutuhan guru pada zaman 4.0 ini, penggunaan teknologi menjadi hal yang sangat dibutuhkan dan menjadi tuntutan guru yan profesional zaman now, oleh karena itu penggunaan perangkat teknologi komputer yang di dalanya terdapat aplikasi musik sangat dianjurkan untuk dipelajari oleg guru seni budaya.

2. Penggunaan Encore sangat membantu para guru seni budaya terutama dalam mempelajari seni musik sebagai bagian dari mata pelajaran seni budaya.

Seperti yang sudah dibahas pada bab sebelumnya bahwa penggunaan encore menjadi booster dan pengalaman yang baru dalam pembelajaran seni musik di sekolah sehingga guru lebih mudah dalam mengajar dan juga tertantang untuk mempelajari aplikasi aplikasi musik yang lain

3. Perlu adanya tindak lanjut untuk memaksimalkan pengetahuan seni musik bagi guru seni budaya

Pengalaman dalam mempelajari encore banyak membuka wawasan untuk lebih mempelajari lanih lanjut dan maksimal dalam menguasai komputer musik sehingga kegiatan penelitian ini akan ditindaklanjuti dengan pembelajaran aplikasi musik yang lain seperti sibelius dan aplikasi lain yang menunjang guru dalam memberikan pembelajaran di sekolah.

Demikianlah kesimpulan yang didapatkan mudah-mudahan bisa memperbaiki kualitas pembelajaran di kelas baik bagi guru seni budaya maupun mempermudah siswa dalam mempelajari seni musik baik teori dasar musik maupun dalam hal mengaransemen.

\section{DAFTAR PUSTAKA}

Adrianus, I.W. Sukmana, I.Y Candiasa \& Kirna (2013). Pengembangan Multimedia pembelajaran Matematik pendekatan kontekstual untuk siswa kelas VIII di SMP Negeri 4 Singaraja. E-Journal Program Studi Teknologi Pembelajaran Program Pascasarjana Universitas Pendidikan Ganesha.

Arikunto, Suharsimi. (1998). Prosedur Penelitian. Jakarta: Rineka Cipta.

Artanto. M. (2016). Mencermati Transit dan Transition Teks Aransemen Musik NyanyianNyanyian Negeriku Karya Singgih Sanjaya ke Pergelaran. Jurnal Kajian Seni 2, 132135.

Banoe, Pono.(2013). Metode Kelas Musik. Jakarta: PT. Indeks.

Firmansyah, F (2016). Proses Aransemen Lagu dalam Bentuk Musik, Tema, dan Variasi: Jurnal Sitakara

Grimonia, Eya. (2014). Dunia Musik. Bandung : Nuansa Cendekia.

Halimah, Lely. (2015). Musik Dalam Pembelajaran. Bandung: Jurnal UPI.

Ivanno, Dani. (2013). Pemanfaatan Software Multimedia dalam Mengaransemen Musik Sebagai Upaya Peningkatan Kompetensi Mahasiswa Program Studi Pendidikan Seni Musik FBS Unimed. Medan: Jurnal Pengabdian Kepada Masyarakat Vol. 19 No 72

Kaestri, V. Y. Dan Widodo, T. W. (2021). Konstruksi aransemen Bagimu Negeri Melalui Penerapan Harmoni dan Kontrafung Dasar. Promusika. Jurnal Pengkajian, Penyajian, dan Penciptaan Musik Vol 9 No 1.

Widodo. T. W. (2015). Pembelajaran Musik Berbasis Teknologi Komputer di Jurusan Musik FSP Institut Seni Indonesia Yogyakarta, Promusika. Jurnal Pengkajian, Penyajian, dan Penciptaan Musik 3, 119-128

Putra \& Ishartiwi, I. (2015). Pengembangan multimedia pembelajaran interatif mengenal angka dan huruf untuk anak Usia Dini. Jurnal Inovasi Teknologi Pendidikan. 